\title{
Optimal Replacement Policy and Economic Value of Dairy Cows with Diverse Health Status and Production Capacity
}

\author{
A.-M. Heikkilä, ${ }^{\star 1}$ J. I. Nousiainen, $†$ and L. Jauhiainen¥ \\ *MTT Agrifood Research Finland, Economic Research, FI-00410 Helsinki, Finland \\ †MTT Agrifood Research Finland, Animal Production Research, Fl-71750 Maaninka, Finland \\ ‡MTT Agrifood Research Finland, Services Unit, Fl-31600 Jokioinen, Finland
}

\begin{abstract}
Understanding optimal replacement practices is essential in milk production management. In this study, we produced a stochastic dynamic optimization model that included the risk of diseases. Moreover, the study took into consideration the genetic production capacity of a cow and the uncertainty related to it. We determined the optimal replacement policy separately for Ayrshire and for Holstein-Friesian Finnish herds. The need for veterinary treatments and the probability of involuntary culling were estimated from the Finnish dairy herd health recording system. We found that the portion of involuntary culling was approximately $50 \%$ of present disposals. The need for veterinary treatments and the probability of involuntary culling were higher for Holstein-Friesian than for Ayrshire cows. Regardless of health status, only the oldest cows with low production capacity should be disposed of intentionally. In the postoptimization steady state, the mean parity was 3.8 and 3.7 for Ayrshire and Holstein-Friesian herds, respectively. Under current management practice, the mean is only 2.3 parities. Preventing premature culling of dairy cows is important to improve the possibilities of breeding selection and the economic performance of milk production. The expected net present value of a cow was slightly higher in Ayrshire than in Holstein-Friesian herds. The results indicate that in the long run, it is worth paying attention to the health status and longevity of a cow as well as to its high yield.
\end{abstract} Key words: dairy cow, replacement, animal disease, dynamic programming

\section{INTRODUCTION}

The average culling age of Finnish dairy cows is 4.9 yr (J. Kyntäjä, ProAgria Association of Rural Advisory Centres, Helsinki, Finland; personal communication).

Received September 28, 2007.

Accepted February 11, 2008.

${ }^{1}$ Corresponding author: anna-maija.heikkila@mtt.fi
The decreasing trend in age stabilized toward the end of 1990s. Nowadays, however, culling age is approximately 2 yr lower than $40 \mathrm{yr}$ ago. A rapid drop took place at the beginning of the 1990s, when the criteria for milk quality became considerably tighter. The present culling age means that the herd life lasts only $2.7 \mathrm{yr}$ and the mean parity of the cows in a herd is 2.3 ( $\mathrm{J}$. Kyntäjä, ProAgria Association of Rural Advisory Centres, Helsinki, Finland; personal communication). The short herd life leads to high replacement costs and limited potential for breeding selection. On the other hand, a rapid cycle of generations may advance genetic progress via bull selection. Consequently, many models have been developed to assist dairy farmers in their culling decisions (Dohoo and Dijkhuizen, 1993; Lehenbauer and Oltjen, 1998).

Among all the previous models, only a few included the effect of a disease (Stott and Kennedy, 1993; Houben et al., 1994; Stott et al., 2002) or of diseases (Gröhn et al., 2003). However, the results of such studies showed that we cannot totally ignore the risk of diseases when determining an optimal replacement policy. Moreover, the data from previous studies have usually consisted of only one breed; thus, there has seldom been an opportunity to compare breeds. Such a comparison, however, is a current topic in Finland, where the HolsteinFriesian breed is growing in popularity relative to the more dominant Ayrshire breed. In general, a comparison is necessary for evaluating the pursuit of high yields, perhaps at the expense of longevity.

The purpose of our study was, first, to find an optimal replacement policy for dairy cows and, second, to investigate the difference in economic value between dairy cow breeds and between diverse cows within the breeds. For this purpose, we developed a stochastic dynamic optimization model. The model was structured separately for Ayrshire and Holstein-Friesian cattle, which enabled us to compare these 2 breeds. We included the risk of diseases and involuntary disposals in our model. This was done on the basis of a thorough analysis of Finnish dairy herd health records. The model also took into account the production capacity of a cow and the 
uncertainty related to it. Because the shortened herd life and its long-term economic consequences were the focus of our interest, the examination was undertaken at the parity level without extending it to the optimization within lactation.

\section{MATERIALS AND METHODS}

\section{Dynamic Programming}

The goal of a milk producer is to find a replacement policy that maximizes the expected net present value of a cow (i.e., the current and future net earnings of a cow and the net earnings of all future cows that replace her; Miranda and Fackler, 2002). In this study, we optimized the timing of replacement by dynamic programming (DP). Dynamic programming is a mathematical technique that is useful in situations in which a sequence of decisions has to be carried out. In this method, a multiperiod optimizing problem can be split into a sequence of 2 period problems. Dynamic programming was initially developed by Bellman (1957), whose principle of optimality forms the basis of the technique. In DP, the principle implies the Markovian property, which postulates that the future state of the resource depends only on the current state of the resource and the current decision (Ljungqvist and Sargent, 2000).

Following Bellman's principle of optimality and the presentation of Kennedy (1986), the optimization problem is formulated as

$$
\begin{gathered}
V_{t}\left(s_{t}\right)=\max _{x_{t}}\left\{R_{t}\left(s_{t}, x_{t}\right)+\beta V_{t+1}\left(s_{t+1}\right)\right\}, t=1,2, \ldots, T \\
\text { subject to } V_{T}\left(s_{T}\right)=F\left(s_{T}\right), s_{1}=\bar{s}_{1} \\
\text { and } s_{t+1}=g\left(s_{t}, x_{t}\right),
\end{gathered}
$$

where the optimal value function $V_{t}$ is the function of current state vector $s_{t}, t$ is the time index, $x_{t}$ is the decision vector, $R_{t}\left(s_{t}, x_{t}\right)$ is the one-period return function, $\beta$ is the discount factor, and $V_{t+1}\left(s_{t+1}\right)$ is the next period value function. $V_{T}\left(s_{T}\right)=F\left(s_{T}\right)$ is the terminal value of the resource at the end of the planning horizon, $\bar{s}_{1}$ is the given initial state of the resource, and $s_{t+1}$ is the state of the next period, which can be given with the transition function $g\left(s_{t}, x_{t}\right)$ once the state $s_{t}$ and decision $x_{t}$ of the current period are known. If the state of the next period is known with certainty, the model is deterministic and the state transition can be given explicitly with a transition function. In the case of a stochastic model, the state transitions are indicated as transition probabilities $p_{t, t+1}(s, x)$, which express the probability of transferring from state $s$ of stage $t$ to state $s$ of stage $t+1$ when the decision is $x$.
The planning horizon of the model may be either finite $(T<\infty)$ or infinite $(T=\infty)$. For the finite horizon, the terminal value function must be specified by the analyst. If the decision problem has an infinite horizon, the value function will not depend on time $t$ but is the same for every stage. Therefore, we may then discard the time subscripts and write the Bellman equation as a vector fixed-point equation whose single unknown is the common value function $V$.

The optimization principle can be defined for discretetime and continuous-time problems. The discrete-time formulation is appropriate for most practical resource problems in agriculture (Kennedy, 1986).

\section{Model Specification}

The optimization model in this study is a discretetime, discrete-state stochastic model. The interval between 2 successive stages is a calving interval that was fixed to $400 \mathrm{~d}$ for every cow. The length of the calving interval refers to the current average in Finnish herds.

The state of a cow was determined at every stage $t$ with 3 state variables:

$$
\begin{aligned}
& s_{t}^{\text {parity }}=\text { lactation number of a cow (parity), }= \\
& \qquad 1,2, \ldots, 10 \\
& s_{t}^{\text {prod }}=\text { production capacity (multiplier } \\
& \text { to the estimated yield) }=0.90,1.00,1.10 \\
& s_{t}^{\text {health }}=\text { health status }=1,2,3
\end{aligned}
$$

(where 1 is no disease, 2 is treatable disease, and 3 is disease or injury that causes involuntary culling). The multipliers to the estimated yield reflect genetic variation in the production capacity of dairy cows.

The decision to be realized at the end of stage $t$ is $x_{t}=0,1(0=$ keep, 1 = replace). The "keep" decision means that the cow will stay in the herd at least one more calving interval. The "replace" decision results in selling the cow concerned and replacing her with a new one at her first lactation. It is assumed that a young cow is always available. A forced replacement decision was determined for the model after the 10th lactation (i.e., if $s_{t}^{\text {parity }}=10$, then $x_{t}=1$ ). The transition function concerning the state of lactation was thus formulated as

$$
\begin{gathered}
s_{t+1}^{\text {parity }}=s_{t}^{\text {parity }}+1, \text { if } x_{t}=0 \\
s_{t+1}^{\text {parity }}=1, \text { if } x_{t}=1 .
\end{gathered}
$$

The uncertainty in the process was represented by 2 groups of transition probabilities, $p_{t, t+1}\left(s^{p r o d}, x\right)$, and 
$p_{t, t+1}\left(s^{\text {health }}, x\right)$, which were multiplied to produce the probability of entering every possible combination of states. A cow remains at the same state of production capacity. That is, the multiplier to the estimated yield is the same for her whole herd life; thus, if the decision is "keep," the probability of transferring from state $s^{\text {prod }}$ at stage $t$ to the same state $s^{\text {prod }}$ on the next stage $t+1$ is equal to 1 . When the decision is "replace," a dairy farmer does not know the production capacity of the replacement cow for sure until the end of her first lactation. The cow's state of production capacity $s^{\text {prod }}$ is obtained from the set of possible states with a given probability $p_{t, t+1}\left(s^{p r o d}, x\right)$. The probabilities of the 3 production states and genetic improvement in the production capacity were derived from a dairy farm data set.

The probability of transferring from the group of healthy cows to the group of cows that need veterinary treatment but will survive or to the group of cows that need veterinary treatment but will be involuntarily culled depends on parity. The probabilities were derived from the Finnish dairy herd health records.

The planning horizon has to be long enough for the decision rules and the value function to converge. We did not have any computational limitations on the choice of planning horizon because the number of state combinations was moderate $(10 \times 3 \times 3)$. Hence, skimping on the number of stages was not necessary and the problem was solved in an infinite planning horizon.

The one-period return function $R\left(s^{\text {parity }}, s^{\text {prod }}, s^{\text {health }}, x\right)$ took the following form in every period of the infinite planning horizon:

$$
\begin{gathered}
R\left(s^{\text {parity }}, s^{\text {prod }}, s^{\text {health }}, x\right)=M R\left(s^{\text {parity }}, s^{\text {prod }}\right) \\
-F C\left(s^{\text {parity }}, s^{\text {prod }}\right)-T C\left(s^{\text {health }}\right)-T L\left(s^{\text {parity }}, s^{\text {prod }}, s^{\text {health }}\right), \\
\text { if } x=0 \\
R\left(s^{\text {parity }}, s^{\text {prod }}, s^{\text {health }}, x\right)=M R\left(s^{\text {parity }}, s^{\text {prod }}\right) \\
-F C\left(s^{\text {parity }}, s^{\text {prod }}\right)-T C\left(s^{\text {health }}\right)-T L\left(s^{\text {parity }}, s^{\text {prod }}, s^{\text {health }}\right) \\
-H C+S R\left(s^{\text {parity }}\right)+G P\left(s^{\text {parity }}\right), \text { if } x=1,
\end{gathered}
$$

where $M R\left(s^{\text {parity }}, s^{\text {prod }}\right)$ is milk return as a function of lactation and production capacity; $F C\left(s^{\text {parity }}, s^{\text {prod }}\right)$ is feed cost as a function of lactation and production capacity; $T C\left(s^{\text {health }}\right)$ is veterinary treatment cost as a function of health status; $T L\left(s^{\text {parity }}, s^{\text {prod }}, s^{\text {health }}\right)$ is the value of production losses as a function of lactation, production capacity, and health status; $H C$ is the cost of a replacement heifer; $S R\left(s^{\text {parity }}\right)$ is the return from selling a cow to a slaughterhouse as a function of lactation; and $G P\left(s^{\text {parity }}\right)$ is the value of genetic progression as a function of lactation. The replacement generates a higher progression the older the cow replaced is. The returns and costs, which are not dependent on the replacement rate, were excluded from the model.

The optimal decision rules were solved numerically with a policy iteration technique (Howard, 1960; Ljungqvist and Sargent, 2000; Bertsekas, 2001) using the CompEcon Toolbox of MATLAB (Miranda and Fackler, 2002). Policy iteration can be used for optimization under an infinite planning horizon and when the number of states is rather small (Kristensen, 1988).

\section{Milk Production, Live Weight, and Feed Consumption}

We predicted milk yields with a test-day model that Lidauer et al. (2000, 2003) developed for evaluating the breeding value of Finnish dairy cattle. As such, the model enables the separation of a pure parity effect on milk production and is superior compared with recorded yields. In the DP model, we used the predicted yields for Ayrshire and Holstein-Friesian cows born in 2003. The milk, protein, and fat yields per lactation were calculated by summing the solutions of breeding value, herd $\times$ year, year $\times$ month, calving year $\times$ calving season, calving age, and days carrying a calf. In the interactions, herd $\times$ year, year $\times$ month, and calving year $\times$ calving season, the average values of herd $\times$ year 2001 were used. Solutions of herd $\times$ year $\times$ month and permanent environmental effects were assumed to be zero.

Estimated milk production for the first 10 lactations is presented in Figure 1. Milk yield increased in the first parities, reaching its maximum after the fifth calving. From the sixth parity onward, milk yield decreased, but rather slowly. The yield of the tenth lactation was higher than the yield of the first lactation, provided that the cow would survive until that.

The fat and protein contents of milk were also estimated, because the price of milk, and thus the milk revenue, depends on them. The trends for both components were downward sloping as the number of parities increased from 1 to 10 . The fat percentage decreased from 4.34 to $4.11 \%$ and from 3.96 to $3.67 \%$ for Ayrshires and Holstein-Friesians, respectively. The corresponding change in protein content was from 3.41 to $3.30 \%$ and from 3.30 to $3.25 \%$. Like the milk yield, the protein and fat yields were highest on the fifth lactation when measured as kilograms.

We also estimated the genetic yields for a sample of dairy cows in our data to find the range of genetic variation in production capacity. The sample, 1,268 herds and 98,806 cows, showed that our state variables "production capacity 0.90 " and "production capacity 1.10 " both represented approximately $5 \%$ of all cows. In these herds, the mean for genetic progress during a 13-yr period was $0.92 \%$ per year for Ayrshires and $1.05 \%$ per 


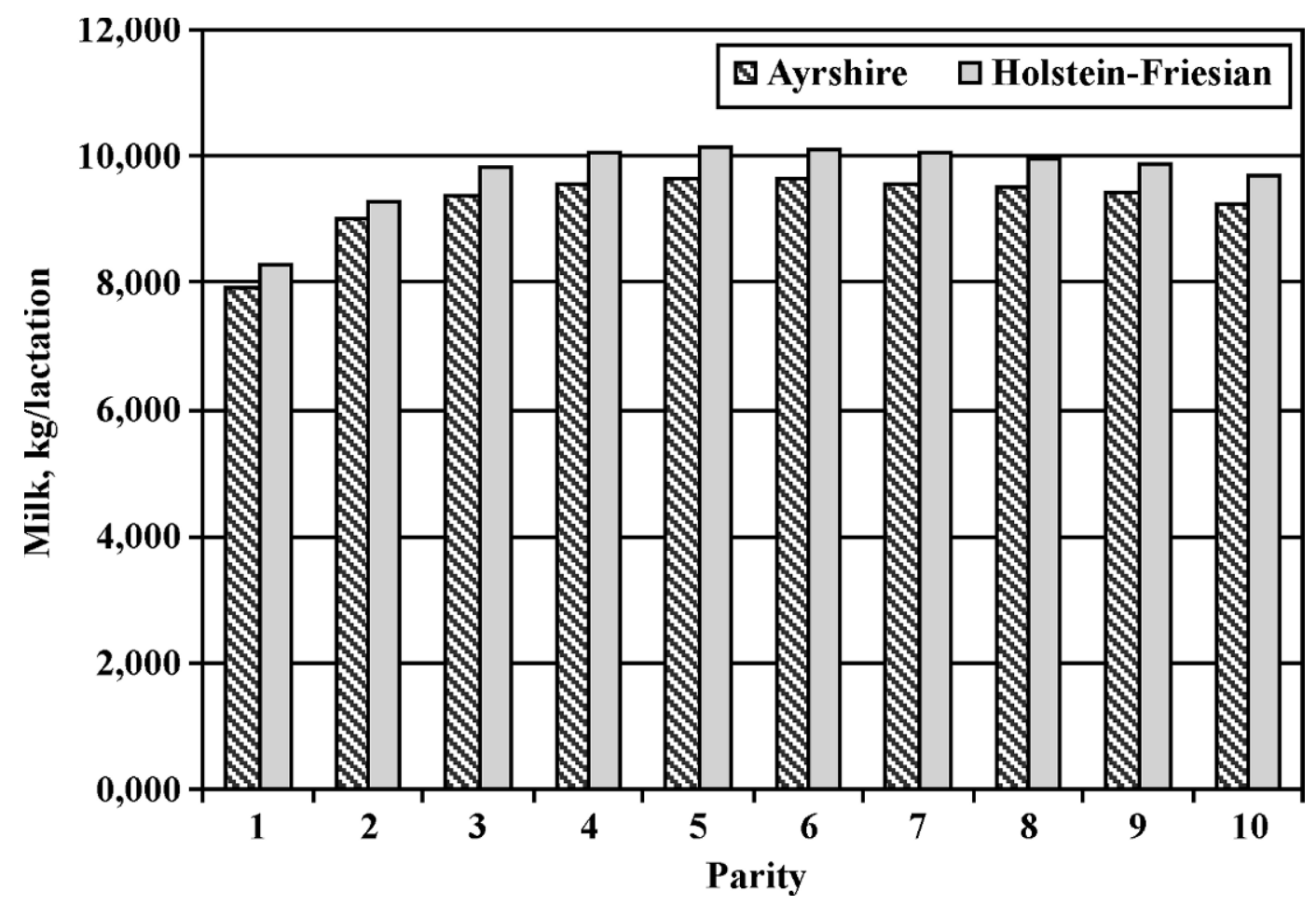

Figure 1. Milk production by breed and parity.

year for Holstein-Friesians. The progress was calculated from milk yield $(\mathrm{kg})$. The protein and fat contents were very stable for the entire research period.

The age of cows at first calving was assumed to be $785 \mathrm{~d}$ and the calving interval $400 \mathrm{~d}$. The BW $(\mathrm{kg})$ of a cow at the beginning of each lactation was calculated as follows with a modification of Richard's growth curve (Perotto et al., 1992):

$$
B W=M W \times\left[1-0.728 \times \mathrm{e}^{(-0.0025 \times \text { age })}\right]^{2.17} .
$$

Age in equation [4] is expressed in days and $M W$ is the mature BW, having the value of 655 and $682 \mathrm{~kg}$ for Ayrshires and Holstein-Friesians, respectively. The growth of a cow per lactation was determined as the difference in her weights on successive parities.

Feed consumption was calculated according to feeding standards (MTT Agrifood Research Finland, 2006) summing the energy requirement for maintenance, growth, production, and pregnancy. The diet was assumed to be composed of typical Finnish feeds (i.e., silage, pasture, and grain complemented with a necessary amount of protein supplement). The average portion of roughage was $50 \%$ of the total consumption of feed units.

\section{Veterinary Treatments and Involuntary Culling}

The need for veterinary treatments was determined from the Finnish health recording system. The sample consisted of 61,477 cows in 2,102 herds and in 2 areas of Rural Centers, Häme in southern Finland and PohjoisSavo in eastern Finland. A 1-yr research period from September 2003 to August 2004 was chosen for the examination. The number of observations in the paritybased analysis was 62,449 for Ayrshires and 29,625 for Holstein-Friesians because approximately half of the cows in the sample calved during the research period and thus represented 2 successive parities. Preventive treatments were excluded from the data. However, intramammary treatments at dry-off were included in the analysis.

The results by breed and parity are presented in Table 1 . The need for treatments increased with age, and it was higher for Holstein-Friesians than for Ayrshires. On average, 29 and $32 \%$ of Ayrshire and HolsteinFriesian cows, respectively, needed some treatment from a veterinarian during the research period. The mean number of treatments per treated cow was 1.5 for both breeds.

The probability that culling was involuntary was estimated from the same sample as the need for veterinary 
Table 1. Need for veterinary treatments and probability of involuntary culling by breed and parity

\begin{tabular}{|c|c|c|c|c|c|c|}
\hline Breed & Parity & $\begin{array}{l}\text { Proportion of } \\
\text { treated cows, } \%\end{array}$ & $\begin{array}{l}\text { Treatments per } \\
\text { treated cow, } \mathrm{n}\end{array}$ & $\begin{array}{l}\text { Probability that } \\
\text { culling is involuntary }\end{array}$ & $\begin{array}{l}\text { Probability of } \\
\text { culling }\end{array}$ & $\begin{array}{c}\text { Probability of } \\
\text { involuntary culling }\end{array}$ \\
\hline \multirow[t]{5}{*}{ Ayrshire } & 1 & 24.13 & 1.38 & 0.39 & 0.23 & 0.09 \\
\hline & 2 & 25.97 & 1.39 & 0.36 & 0.30 & 0.11 \\
\hline & 4 & 36.86 & 1.56 & 0.43 & 0.47 & 0.20 \\
\hline & 5 & 39.14 & 1.64 & 0.44 & 0.53 & 0.23 \\
\hline & $\geq 6$ & 48.63 & 1.81 & 0.46 & 0.57 & 0.26 \\
\hline \multirow[t]{4}{*}{ Holstein-Friesian } & 1 & 28.01 & 1.40 & 0.48 & 0.22 & 0.10 \\
\hline & 4 & 41.14 & 1.67 & 0.49 & 0.47 & 0.23 \\
\hline & 5 & 39.85 & 1.82 & 0.51 & 0.54 & 0.28 \\
\hline & $\geq 6$ & 49.00 & 2.01 & 0.48 & 0.59 & 0.28 \\
\hline
\end{tabular}

treatments. The data consisted of 11,082 Ayrshire and 5,061 Holstein-Friesian cows that were disposed of during the research period. The definition of involuntary disposals was based on a reported culling reason and the means of departure. If the reported culling reason was connected with udder health or reproductive status, and if the reason was "other reason" or the reason was missing, the necessity of culling was defined with the help of inseminations, veterinary treatments, and test-day results.

Disposals were regarded as involuntary if a cow was dead or slaughtered on a farm if the culling reason was an accident, an injury, foot and leg diseases, calving difficulty, alimentary canal disease, parturient paresis, or other illness. Furthermore, cullings that occurred within $22 \mathrm{~d}$ after the latest insemination were considered involuntary. Culling because of low production was regarded as involuntary only when the cow was dead or slaughtered on a farm. Culling was defined as involuntary with the culling reasons were mastitis, teat disease or injury, and udder conformation if 2 or more SCC greater than 500,000 cells $/ \mathrm{mL}$ or udder-related veterinary treatments were recorded within $90 \mathrm{~d}$ before the previous calving or on the lactation when a cow was culled. Reproductive status was the reason for involuntary culling if the number of inseminations and the number of reproductive treatments, respectively, fulfilled the following conditions during the lactation when a cow was culled: $0, \geq 3 ; 1$ to $2, \geq 3 ; 3$ to $5, \geq 1 ; \geq 6,0$.

In the case of other culling reasons or a missing reason (provided that the cow was sold to a slaughterhouse), the definition of compulsion was based on the history of udder health and reproductive status in the same way as they were used when udder health or reproductive status was reported as the reason for culling.

In the analysis of the data, we used logistic regression, in which the response variable was the probability that an event would occur (culling was involuntary, not voluntary). Categorical explanatory variables were parity, breed, and their interaction. Parity 3 and breed Ayrshire were used as control groups.

If $z$ is the vector of explanatory variables presented above, and $P$ is the response probability to be modeled, then the linear logistic model is

$$
\operatorname{logit}(P)=\alpha+\boldsymbol{\beta}^{\prime} \boldsymbol{z},
$$

where $\alpha$ and $\beta$ are parameters. The probability that culling is involuntary, $p(\boldsymbol{z})$, can be expressed as follows:

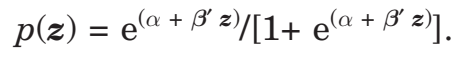

The Wald $\chi^{2}$ test indicated that both parity and breed had a statistically significant effect on the probability of involuntary culling $(P<0.001)$. The effect of parity was similar for both breeds $(P=0.38)$.

Furthermore, we estimated the probability that a cow would be culled from the same herds and by the same method as we estimated the necessity of culling. We followed the history of 65,923 cows from their calvings in 2001 and 2002 to their next calving or to their culling. Ayrshire cows had 65,372 calvings and HolsteinFriesian cows had 30,042 calvings during those $2 \mathrm{yr}$. The number of culled Ayrshire cows was 22,453. The corresponding figure for Holstein-Friesian cows was 9,870 . The effect of parity on the probability of culling was distinct $(P<0.001)$, whereas the effect of breed was small and was not statistically significant $(P=$ $0.14)$. The parity effect was nearly the same in both breeds $(P=0.06)$.

By multiplying the probability that the culling was involuntary and the probability of culling, we could define the probability of involuntary culling for the model. Nearly similar culling rates, but a higher share of involuntary culling for Holstein-Friesians, resulted in a higher probability of involuntary culling for Holstein-Friesian cows than for Ayrshire cows (Table 1). 


\section{Other Inputs and Prices}

The price of a replacement heifer is an essential variable in the model. Most Finnish dairy farms raise heifers alongside their dairy cows; thus, the heifer market is minor. That is why a production cost was selected to be the basis in setting the price. A cost of $€ 1,685$ was calculated to represent the production cost of a heifer whose age at first calving was around the average (26 mo) and that had been raised in a modern Finnish dairy farm (64 cows and technology appropriate for the size) where the work input, and thus the production cost of a heifer, is lower than on average. In the calculation, we did not distinguish between the breeds. On the basis of the difference in the market price of inseminated heifers, we set the price of $€ 1,600$ and $€ 1,750$ for an Ayrshire and a Holstein-Friesian heifer, respectively. [The mean market price of an inseminated heifer was $€ 1,179$ and $€ 1,289$ in 2005 for an Ayrshire and HolsteinFriesian heifer, respectively (P. Taurén, FABA-Animal Breeding Center, Vantaa, Finland; personal communication).] The price of feed was set at 22 euro $\phi /$ feed unit. The price was based on the composition of the feed unit and the production costs or market prices of the feeds (ProAgria, 2006).

The basic milk price in 2006 of 30.67 euro $\phi / L$, was the price for milk with $4.3 \%$ fat and $3.3 \%$ protein and of quality class 1 . In addition to the basic price, a producer received a quality addition-the mean being 2.26 euro $\phi / \mathrm{L}$-and a cooperative adjustment payment of 3.46 euro $\phi / L$ (Tike, 2007). This adjustment payment was based on the result of a dairy on the accounting year concerned. Deviation of protein and fat contents from the basic price level affected the price of the milk. The protein price was \pm 0.631 euro $\phi / 0.1 \%$ and the fat price was \pm 0.233 euro $\phi / 0.1 \%$. A production subsidy was set as it was paid to the producers in central Finland (subsidy area $\mathrm{C} 2$ ), the most important area of milk production. The subsidy level in 2006 was 8.1 euro $\phi / L$. Thus, the total price of milk with basic fat and protein contents and of average quality was 44 euro $\phi / L$.

The cost of veterinary treatment was calculated as a weighted mean of the treatment costs determined by Toivakka et al. (2005). The weights were calculated from the Finnish health recording system, with the years from 1995 to 2002 as the period observed. The total number of treatment observations was 2,110,351. Mastitis and other udder diseases were the most common reason for treatment (23.3\%). Fertility problems took the second place (17.0\%) and milk fever the third place (6.1\%). The average treatment cost was $€ 65$ per treatment in 2004 (Toivakka et al., 2005). After an index correction (Statistics Finland, 2007), we set a price of $€ 80$ per treatment in the model.
The estimation of milk losses because of diseases was based on the investigations of Rajala and Gröhn (1998) and Rajala-Schultz et al. (1999a,b), who studied the effect of diseases on Ayrshire cows in Finland. The effects of dystocia, retained placenta, metritis, milk fever, ketosis, lameness, and clinical mastitis on milk yield were reported. The impact of the diseases varied across parities and stage of lactation. Weighting the total losses by the frequency of diseases in our data, we obtained $180 \mathrm{~kg}$ to be the level of the average loss. It was approximately $3 \%$ of the average yield of Finnish dairy cows in 1993, which was the research period of these studies. In our model, we used this $3 \%$, multiplied by the number of treatments, as an estimate of the milk losses for every cow that ended in the state of being a diseased cow.

The carcass weight of a culled cow was assumed to be $40 \%$ of its live weight. The price of meat was set at $€ 1.45 / \mathrm{kg}$, expressing the mean market price of beef (cows) in 2006 (Tike, 2007). The exogenous discount factor of the model was set at 0.95 . This refers to the annual interest rate of 5\%, which is widely used as a standard in the profitability calculations in Finnish agriculture.

The production costs of feeds and replacement heifers vary widely from farm to farm. There may also be variation in market prices because the prices follow the changes in the markets of agricultural products. Therefore, the sensitivity of the results according to the price changes in milk, feed, treatment, and replacement heifers was tested in the study. The quantity of the change tested was $\pm 20 \%$ for each price. A sensitivity analysis was also done with respect to production capacity. Instead of $\pm 10 \%$, the effects of the variation of $\pm 15 \%$ in production capacity were analyzed.

\section{RESULTS}

The optimal decisions were dependent on the production potential of a cow. Voluntary replacement was optimal only for the oldest cows with low production capacity. It was optimal to keep cows with an average or high production capacity in the herd as long as possible, in the model until their 10th lactation. Treatable diseases did not affect the optimal decisions. Within the same production capacity state, the decisions were similar for both healthy cows and cows with treatable diseases. A noteworthy fact here is that involuntarily culled cows were also assumed to be diseased or injured cows.

The herd structures in a postoptimization steady state are presented in Table 2 (Ayrshires) and Table 3 (Holstein-Friesians). The steady state was reached by realizing the optimal decisions in voluntary cullings and as a result of assumed probabilities of involuntary 
Table 2. Distribution of cows by parity, production capacity, and health status in a steady-state Ayrshire herd $(\%)$

\begin{tabular}{|c|c|c|c|c|c|c|c|c|c|c|}
\hline \multirow[b]{2}{*}{ Parity } & \multicolumn{3}{|c|}{ Production capacity 0.90} & \multicolumn{3}{|c|}{ Production capacity 1.00} & \multicolumn{3}{|c|}{ Production capacity 1.10} & \multirow[b]{2}{*}{ Total } \\
\hline & $\mathrm{A}^{1}$ & $\mathrm{~B}^{2}$ & $\mathrm{C}^{3}$ & $\mathrm{~A}^{1}$ & $\mathrm{~B}^{2}$ & $\mathrm{C}^{3}$ & $\mathrm{~A}^{1}$ & $\mathrm{~B}^{2}$ & $\mathrm{C}^{3}$ & \\
\hline 1 & 0.7 & 0.1 & 0.1 & 13.1 & 2.7 & 1.6 & 0.7 & 0.1 & 0.1 & \\
\hline 2 & 0.6 & 0.1 & 0.1 & 11.7 & 2.5 & 1.7 & 0.6 & 0.1 & 0.1 & 17 \\
\hline 3 & 0.5 & 0.1 & 0.1 & 9.5 & 2.4 & 2.3 & 0.5 & 0.1 & 0.1 & 15 . \\
\hline 4 & 0.4 & 0.1 & 0.1 & 7.4 & 2.1 & 2.4 & 0.4 & 0.1 & 0.1 & 13. \\
\hline 5 & 0.3 & 0.1 & 0.1 & 5.6 & 1.6 & 2.2 & 0.3 & 0.1 & 0.1 & 10. \\
\hline 6 & 0.2 & 0.1 & 0.1 & 3.6 & 1.7 & 1.9 & 0.2 & 0.1 & 0.1 & 8 \\
\hline 7 & 0.1 & 0.1 & 0.1 & 2.7 & 1.3 & 1.4 & 0.1 & 0.1 & 0.1 & 6 \\
\hline 8 & 0.1 & 0.1 & 0.1 & 2.0 & 0.9 & 1.0 & 0.1 & 0.1 & 0.1 & \\
\hline 9 & 0.0 & 0.0 & 0.0 & 1.5 & 0.7 & 0.8 & 0.1 & 0.0 & 0.0 & \\
\hline 10 & 0.0 & 0.0 & 0.0 & 1.1 & 0.5 & 0.6 & 0.1 & 0.0 & 0.0 & 2.3 \\
\hline Total & 2.9 & 0.8 & 0.8 & 58.2 & 16.4 & 15.9 & 3.1 & 0.8 & 0.8 & 100.0 \\
\hline
\end{tabular}

${ }^{1}$ No diseases.

${ }^{2}$ Treatable diseases.

${ }^{3}$ Involuntary culling.

cullings. In this steady state, the mean parity for the cows in a herd was 3.8 for Ayrshires and 3.7 for Holstein-Friesians. The mean parity of culled cows was 5.1 for Ayrshires and 4.8 for Holstein-Friesians. Only $19.4 \%$ of an Ayrshire herd (Table 2) and $20.3 \%$ of a Holstein-Friesian herd (Table 3) were replaced annually. Most of the replacements were involuntary, 90 and $93 \%$ of the total number in an Ayrshire and in a Holstein-Friesian herd, respectively.

The expected net present value of a cow (i.e., the expected net present value of current and replacement cows over the decision horizon) was the highest for cows with a high production capacity. Within the production capacity, healthy cows received the highest value and involuntarily culled cows the lowest value, with the value of diseased cows falling between them. The weighted average in the steady state was $€ 40,196$ in an Ayrshire herd (Table 4) and €40,052 (i.e., 0.4\% lower) in a Holstein-Friesian herd (Table 5). Tables 4 and 5 also present the weighted averages over different parities for each production capacity and health state as well as for each parity over different production capacities and health states.

Because only those returns and costs that varied by replacement strategy were included in the model, the net present values are not valid to evaluate the profitability of milk production but only to compare different cows. The differences between the health states express the losses that milk producers had to meet because of disease and premature culling. The losses caused by diseases varied between $€ 261$ and $€ 479$ per lactation depending on the breed, parity, and production capacity. The weighted average was approximately $€ 400$ regardless of the breed (Tables 4 and 5). The correspond-

Table 3. Distribution of cows by parity, production capacity, and health status in a steady-state HolsteinFriesian herd (\%)

\begin{tabular}{|c|c|c|c|c|c|c|c|c|c|c|}
\hline \multirow[b]{2}{*}{ Parity } & \multicolumn{3}{|c|}{ Production capacity 0.90} & \multicolumn{3}{|c|}{ Production capacity 1.00} & \multicolumn{3}{|c|}{ Production capacity 1.10} & \multirow[b]{2}{*}{ Total } \\
\hline & $\mathrm{A}^{1}$ & $\mathrm{~B}^{2}$ & $\mathrm{C}^{3}$ & $\mathrm{~A}^{1}$ & $\mathrm{~B}^{2}$ & $\mathrm{C}^{3}$ & $\mathrm{~A}^{1}$ & $\mathrm{~B}^{2}$ & $\mathrm{C}^{3}$ & \\
\hline 1 & 0.7 & 0.2 & 0.1 & 13.2 & 3.3 & 1.9 & 0.7 & 0.2 & 0.1 & 20.4 \\
\hline 2 & 0.6 & 0.2 & 0.1 & 11.7 & 2.8 & 2.0 & 0.6 & 0.2 & 0.1 & 18.3 \\
\hline 3 & 0.5 & 0.1 & 0.1 & 9.5 & 2.6 & 2.4 & 0.5 & 0.1 & 0.1 & 15.9 \\
\hline 4 & 0.4 & 0.1 & 0.2 & 7.0 & 2.3 & 2.8 & 0.4 & 0.1 & 0.2 & 13.5 \\
\hline 5 & 0.3 & 0.1 & 0.1 & 5.5 & 1.2 & 2.6 & 0.3 & 0.1 & 0.1 & 10.3 \\
\hline 6 & 0.2 & 0.1 & 0.1 & 3.3 & 1.5 & 1.9 & 0.2 & 0.1 & 0.1 & 7.5 \\
\hline 7 & 0.1 & 0.1 & 0.1 & 2.4 & 1.1 & 1.3 & 0.1 & 0.1 & 0.1 & 5.4 \\
\hline 8 & 0.1 & 0.0 & 0.1 & 1.7 & 0.8 & 1.0 & 0.1 & 0.0 & 0.1 & 3.9 \\
\hline 9 & 0.1 & 0.0 & 0.0 & 1.2 & 0.6 & 0.7 & 0.1 & 0.0 & 0.0 & 2.7 \\
\hline 10 & 0.0 & 0.0 & 0.0 & 0.9 & 0.4 & 0.5 & 0.0 & 0.0 & 0.0 & 1.8 \\
\hline Total & 3.0 & 0.9 & 0.9 & 56.4 & 16.6 & 17.1 & 3.0 & 0.9 & 0.9 & 100.0 \\
\hline
\end{tabular}

${ }^{1}$ No diseases.

${ }^{2}$ Treatable diseases.

${ }^{3}$ Involuntary culling. 
Table 4. Weighted average of the expected net present value by the state of the current cow in a steadystate Ayrshire herd (€)

\begin{tabular}{|c|c|c|c|c|c|c|c|}
\hline \multirow[b]{2}{*}{ Parity } & \multicolumn{3}{|c|}{ Production capacity } & \multicolumn{3}{|c|}{ Health status } & \multirow[b]{2}{*}{ Parity } \\
\hline & 0.90 & 1.00 & 1.10 & $\mathrm{~A}^{1}$ & $\mathrm{~B}^{2}$ & $\mathrm{C}^{3}$ & \\
\hline 1 & 38,962 & 40,229 & 41,463 & 40,431 & 40,155 & 38,702 & 40,227 \\
\hline 2 & 39,280 & 40,460 & 41,612 & 40,681 & 40,380 & 39,062 & 40,459 \\
\hline 3 & 39,353 & 40,387 & 41,509 & 40,685 & 40,357 & 39,195 & 40,391 \\
\hline 4 & 39,340 & 40,273 & 41,325 & 40,606 & 40,261 & 39,262 & 40,279 \\
\hline 5 & 39,279 & 40,139 & 41,082 & 40,480 & 40,114 & 39,293 & 40,143 \\
\hline 6 & 39,213 & 39,987 & 40,812 & 40,372 & 39,970 & 39,277 & 39,989 \\
\hline 7 & 39,141 & 39,892 & 40,470 & 40,235 & 39,837 & 39,290 & 39,883 \\
\hline 8 & 39,146 & 39,778 & 40,268 & 40,071 & 39,677 & 39,299 & 39,769 \\
\hline 9 & & 39,625 & 40,432 & 39,905 & 39,476 & 39,295 & 39,651 \\
\hline 10 & & 39,462 & 39,947 & 39,681 & 39,268 & 39,268 & 39,484 \\
\hline State & 39,212 & 40,193 & 41,188 & 40,498 & 40,101 & 39,186 & 40,196 \\
\hline
\end{tabular}

${ }^{1}$ No diseases.

${ }^{2}$ Treatable diseases.

${ }^{3}$ Involuntary culling.

ing losses because of involuntary cullings were far greater, from $€ 366$ to $€ 2,983$ per lactation. The mean was $€ 1,312$ for Ayrshires (Table 4) and €1,461 for Holstein-Friesians (Table 5). The significance of the production capacity of the cow can be seen in the net preset values; on average, the variation of $10 \%$ in the capacity caused a change of approximately $€ 1,000$ in the value (Tables 4 and 5). In the comparison of parities, a cow on her second lactation had the highest value. However, the decrease with increasing age was very slow (Tables 4 and 5).

The net present value of the cow would be $€ 2,473$ and $€ 2,791$ higher in an Ayrshire herd and in a HolsteinFriesian herd, respectively, if there were no diseases. Without diseases, the net present value would be $€ 174$ (i.e., 0.4\% higher) for Holstein-Friesians than for Ayrshires. Without involuntary culling, the corresponding difference would be $€ 805$ (i.e., 1.8\%), also in favor of
Holstein-Friesian cows. The net present value of the cow would be $€ 4,157$ and $€ 5,107$ higher in an Ayrshire herd and in a Holstein-Friesian herd, respectively, if a dairy farmer managed to avoid involuntary cullings.

The results concerning the optimal decision proved to be very stable. In the sensitivity analysis, the effects of changes in input and output prices were tested. In most cases, an increase or decrease of $20 \%$ in the price of milk, feed, treatment, or the replacement heifer did not change the optimal decisions. The only exceptions were the decisions concerning the oldest cows with a low production capacity. The model recommended postponing their culling when the price of milk decreased or the price of the replacement heifer increased. Compared with the basic solution, earlier culling was optimal if the price of feed or the heifer decreased, or if the price of milk increased. However, even these cows were recommended to be kept for 5 or 6 lactations.

Table 5. Weighted average of the expected net present value by the state of the current cow in a steadystate Holstein-Friesian herd $(€)$

\begin{tabular}{|c|c|c|c|c|c|c|c|}
\hline \multirow[b]{2}{*}{ Parity } & \multicolumn{3}{|c|}{ Production capacity } & \multicolumn{3}{|c|}{ Health status } & \multirow[b]{2}{*}{ Parity } \\
\hline & 0.90 & 1.00 & 1.10 & $\mathrm{~A}^{1}$ & $\mathrm{~B}^{2}$ & $\mathrm{C}^{3}$ & \\
\hline 1 & 38,846 & 40,084 & 41,326 & 40,328 & 40,046 & 38,456 & 40,084 \\
\hline 2 & 39,158 & 40,316 & 41,482 & 40,583 & 40,273 & 38,822 & 40,317 \\
\hline 3 & 39,241 & 40,246 & 41,356 & 40,579 & 40,221 & 38,958 & 40,251 \\
\hline 4 & 39,155 & 40,096 & 40,918 & 40,509 & 40,133 & 39,035 & 40,090 \\
\hline 5 & 39,139 & 39,967 & 40,958 & 40,393 & 39,984 & 39,057 & 39,975 \\
\hline 6 & 39,045 & 39,822 & 40,672 & 40,275 & 39,824 & 39,037 & 39,826 \\
\hline 7 & 38,938 & 39,728 & 40,305 & 40,123 & 39,675 & 39,046 & 39,716 \\
\hline 8 & 38,990 & 39,586 & 40,024 & 39,942 & 39,494 & 39,056 & 39,578 \\
\hline 9 & 39,195 & 39,427 & 40,293 & 39,722 & 39,276 & 39,057 & 39,451 \\
\hline 10 & & 39,246 & & 39,464 & 39,028 & 39,028 & 39,246 \\
\hline State & 39,073 & 40,050 & 41,068 & 40,403 & 40,001 & 38,942 & 40,052 \\
\hline
\end{tabular}

\footnotetext{
${ }^{1}$ No diseases.

${ }^{2}$ Treatable diseases.

${ }^{3}$ Involuntary culling.
} 
The changes in prices dramatically affected the expected net present value, although the decisions were quite stable. For example, a reduction in the milk price by $20 \%$ would drop the mean value of the cow to $€ 24,841$, which was only $62 \%$ of the original value in an Ayrshire herd (Table 4). The respective figures in a Holstein-Friesian herd were $€ 24,084$ and $60 \%$ (Table 5 ). Thus, a decrease in the milk price would increase the difference between the breeds from 0.4 to $3.0 \%$, in favor of the Ayrshire. A change of $+20 \%$ in milk price would cause the net present value of a cow to be higher in a Holstein-Friesian herd than in an Ayrshire herd.

Variation in genetic production capacity was not very wide. In our data, the maximum was approximately $\pm 15 \%$. Multipliers of $0.85,1.00$, and 1.15 , instead of $0.90,1.00$, and 1.10 , for the estimated yields changed the optimal decisions in the category of low production. In this category, voluntary replacement was the optimal decision for Ayrshire cows regardless of their parity. Five lactations was the optimal age for HolsteinFriesian cows with a low production capacity.

\section{DISCUSSION}

The model presented in this paper is not as complicated as several earlier models. However, its results are consistent with previous models, especially concerning the profitability of treating diseased cows. At the aggregate level, our investigation is not sufficient to support a dairy farmer in a single culling replacement decision where a certain disease and an exact replacement time are concerned. Instead, this model gives an extensive general view of the optimal replacement policy in production circumstances in which cows suffer from several treatable or fatal diseases, and it answers the question of optimal timing for replacement at the lactation level.

The data used as an input in the optimization model were based on thorough investigations of biological interrelationships in milk production. The change in milk yield by parity is an essential parameter in the model. We estimated the milk yields with a test-day model that was developed for the estimation of breeding value. Thus, we produced parameters that particularly described the production capacity of cows, not their observed yields, as our problem demanded. This method also guaranteed us parameters that were stripped of all other effects but parity. Estimated yields showed a slower decrease in production after the fifth parity compared with, for example, those of Stott et al. (2002), who collected their data from the United Kingdom National Milk Records. In addition, Kennedy and Stott (1993) emphasized the cow's milk yield potential as an important determining factor in their replacement decisions. They highlighted the difficulty of assessing it from recorded yields and the problems that censored data of later lactations might cause.

Related to our lactation-based investigation, we assumed the calving interval to be similar (400 d) for both breeds. This was done to preserve the straight comparability of lactation-based results when the length of the lactation was equal. In the recorded calving intervals (2006), the difference between the breeds was $4 \mathrm{~d}$ : $402 \mathrm{~d}$ for Holstein-Friesians and $406 \mathrm{~d}$ for Ayrshires (J. Kyntäjä, ProAgria Association of Rural Advisory Centres, Helsinki, Finland; personal communication). The difference should be taken into consideration when building a more detailed model to function as a tool in case-specific optimization. However, in this type of aggregate-level study, this simplification probably had no effect on the results. The model of a casespecific study should also include several seasonal effects, for example, the seasonal price of milk and seasonal variation in the conception rate, which were excluded from our study.

The Finnish health recording system has established its position as a reliable follow-up method during its $25 \mathrm{yr}$ of activity. It offers possibilities of investigating the frequency of treatments by breed, parity, phase of lactation, and type of treatment. The data offered us an opportunity for a comprehensive investigation of diseases, their effect on the optimal replacement policy, and the expected net present value of a cow.

An in-depth investigation of culling reasons preceded the estimation of the probability of involuntary culling. Generally, producer-reported reasons are not considered very reliable; for example, a voluntary culling may be hidden behind an involuntary culling reason. Therefore, inseminations, veterinary treatments, and testday results fulfilled the definition criteria of involuntary culling, with the most complicated reasons reported. The probability determined in our study was, to some extent, higher than that in earlier research. Gröhn et al. (2003) estimated the probability of culling on the basis of the risk caused by common diseases plus a "residual" culling. In different scenarios presented by Gröhn et al. (2003), the risk of involuntary culling varied from 10 to $18 \%$, whereas in our model, the respective figures were from 9 to $28 \%$ by breed and parity. DeLorenzo et al. (1992) applied an involuntary culling risk of $21 \%$.

In previous studies, only a part of veterinary treatments were included in the models; thus, no results were entirely comparable to those of this study as far as diseases were concerned. Stott and Kennedy (1993) concluded that an economically viable culling policy should be based on clinical mastitis records in addition to milk production potential. In our study, the milk 
production potential proved to be a more important factor than the health status when an optimal replacement strategy was determined. This may result from the fact that involuntary culling partially captured the disease effects in our model and thus diminished the impacts of treatable diseases on the economically optimal decisions. Houben et al. (1994) investigated dairy cows in Dutch conditions. They found that, in most cases, the optimal decision was to keep and to treat rather than to replace a cow having clinical mastitis. This result supports the findings of our study. However, if subclinical mastitis caused by Staphylococcus aureus occurred in the herd, extra culling was justified to reduce the level of infection (Stott et al., 2002). Reported cure rates for Staph. aureus infections after antimicrobial treatments vary but are, in general, relatively low (Barkema et al., 2006).

The replacement model of Gröhn et al. (2003) included effects of 9 common diseases. However, the incidence of diseases was obtained from literature from different sources and thus represented dissimilar New York State or Finnish production conditions. The results of Gröhn et al. (2003) indicated that adding diseases in the model did not increase the voluntary or total culling rate. On the contrary, Gröhn et al. (2003) reported an increased herd life when diseases were included in the model. This means that the diseases decreased the culling rate, which is quite surprising. In our study, the herd life decreased slightly with treatable diseases in the model. Gröhn et al. (2003) did not recommend replacing cows in the highest production capacity even if they had contracted a disease. The same advice can be given based on our study, whereas optimal decisions concerning cows with average or low production capacity differ from each other in these 2 studies. For example, all average cows should be kept, according to our results, whereas the results of Gröhn et al. (2003) indicate that it is profitable to replace at least some of the diseased cows. The differences may result from varying definitions of diseased cows, involuntary culling, and production level. Different price relationships in the production conditions may also be a source of variation in the results.

Rajala-Schultz et al. (2000) published the only earlier study that was based on Finnish data. Diseases were not included in that optimization model. The results indicated that average herd life after the first calving was 48.2 mo (i.e., approximately 4 complete lactations). In the base optimal solution, the total replacement rate was $26 \%$, including voluntary and involuntary culling. When the price of a replacement heifer increased from $€ 1,180$ (FIM7,000) to $€ 1,520$ (FIM9,000), total replacement percentage decreased to $23 \%$, which corresponds to our result in a Holstein-Friesian herd, where the heifer price was $€ 1,750$ and the variation range in production capacity was $\pm 15 \%$. McCullough and DeLorenzo (1996) reported an average herd life of 32 mo under Florida conditions. According to the model of Cardoso et al. (1999), the optimal average herd life was 54.9 mo if selling for slaughter was the only possibility of disposal. The herd life corresponded to annual replacement and voluntary culling rates of 21.8 and $4.1 \%$, respectively. Variation in the results shows that the optimal replacement rate depends on local conditions. However, there are some general features that seem to be valid everywhere: the importance of the production potential of a cow and the profitability of treating at least cows with a high production capacity, rather than replacing them because of a disease.

The optimization model also produced the net present value of cows. When drawing conclusions from these values, we have to remember that the model included only feeding, treatment, and replacement costs, and all other costs were assumed to be fixed costs. This type of evaluation produced somewhat higher values for Ayrshire cows than for Holstein-Friesian cows. When the farmer's goal is to minimize the production costs of a certain amount of milk, for example, because of a quota limitation, he or she should also take into account investment and labor costs. In such a comparison, Holstein-Friesian cows with a higher production capacity may beat Ayrshire cows, although their higher risk of involuntary culling increases the need for replacement heifers and thus the need for capacity units for young cattle.

Price movements of milk and production inputs implied large income effects because management practices can only partially adjust to these movements. Thus, carrying out the optimal replacement policy does not guarantee a good economic performance in milk production. It may only relieve the effects of unfavorable price relations.

\section{CONCLUSIONS}

Increasing the herd life of Finnish dairy cows is possible because less than half of the disposals are involuntary. The results suggest that it is also profitable. However, we cannot give any single replacement rate that would be optimal in every herd because the optimal rate is dependent, among other things, on the distribution of cows to diverse production capacities. Regardless of the state of health, it is profitable to dispose intentionally only of cows with the lowest production capacity of the herd.

Preventing premature culling of dairy cows is important to improve the possibilities of breeding selection and the economic performance of milk production. In- 
vesting in the veterinary treatment of dairy cows is profitable, at least where a cow of average or high production capacity is concerned. The Holstein-Friesian breed loses the benefit of its high production level because of high morbidity and a high probability of involuntary culling. This is a fact that should be taken into consideration when planning the breeding programs of dairy cattle and when setting weights for different traits in the total breeding value.

\section{ACKNOWLEDGMENTS}

The authors are grateful to ProAgria Association of Rural Advisory Centres (Helsinki, Finland), FABA Breeding (Vantaa, Finland), and Finnish Agricultural Data Processing Centre Ltd. (Vantaa, Finland) for providing the data, to Valio Ltd. (Helsinki, Finland) and the Ministry of Agriculture and Forestry (Helsinki, Finland) for their financial support of this work, and to Igor Cersosimo and Mitri Kitti for their help in building the first versions of the model. The comments of Kyösti Pietola on the manuscript are greatly appreciated.

\section{REFERENCES}

Barkema, H. W., Y. H. Schukken, and R. N. Zadoks. 2006. 2006. Invited review: The role of cow, pathogen, and treatment regimen in the therapeutic success of bovine Staphylococcus aureus mastitis. J. Dairy Sci. 89:1877-1895.

Bellman, R. E. 1957. Dynamic Programming. Princeton University Press, Princeton, NJ.

Bertsekas, D. P. 2001. Dynamic Programming and Optimal Control. Vol. 2: Dynamic Programming. 2nd ed. Athena Scientific, Belmont, MA.

Cardoso, V. L., J. R. Nogueira, and J. A. M. Van Arendonk. 1999. Optimal replacement and insemination policies for Holstein cattle in the southeastern region of Brazil: The effect of selling animals for production. J. Dairy Sci. 82:1449-1458.

DeLorenzo, M. A., T. H. Spreen, G. R. Bryan, D. K. Beede, and J. A. M. Van Arendonk. 1992. Optimizing model: Insemination, replacement, seasonal production, and cash flow. J. Dairy Sci. 75:885-896

Dohoo, I. R., and A. A. Dijkhuizen. 1993. Techniques involved in making dairy cow culling decisions. Compend. Contin. Educ. Pract. Vet. 15:515-519.

Gröhn, Y. T., P. J. Rajala-Schultz, H. G. Allore, M. A. DeLorenzo, J. A. Hertl, and D. T. Galligan. 2003. Optimizing replacement of dairy cows: Modeling the effects of diseases. Prev. Vet. Med. 61:27-43.

Houben, E. H. B., R. B. M. Huirne, A. A. Dijkhuizen, and A. R. Kristensen. 1994. Optimal replacement of mastitic cows determined by a hierarchic Markov process. J. Dairy Sci. 77:2975-2993.

Howard, R. A. 1960. Dynamic Programming and Markov Processes. John Wiley and Sons, New York, NY.
Kennedy, J. O. S. 1986. Dynamic Programming: Applications to Agriculture and Natural Resources. Elsevier Applied Science Publishers, London, UK.

Kennedy, J. O. S., and A. W. Stott. 1993. An adaptive decision-making aid for dairy cow replacement. Agric. Syst. 42:25-39.

Kristensen, A. R. 1988. Hierarchic Markov processes and their applications in replacement models. Eur. J. Oper. Res. 35:207-215.

Lehenbauer, T. W., and J. W. Oltjen. 1998. Dairy cow culling strategies: Making economical culling decisions. J. Dairy Sci. 81:264-271.

Lidauer, M., E. A. Mäntysaari, and I. Strandén. 2003. Comparison of test-day models for genetic evaluation of production traits in dairy cattle. Livest. Prod. Sci. 79:73-86.

Lidauer, M., E. A. Mäntysaari, I. Strandén, and J. Pösö. 2000. Multiple-trait random regression test-day model for all lactations. Interbull Bull. 25:81-86.

Ljungqvist, L., and T. J. Sargent. 2000. Recursive Macroeconomic Theory. MIT Press, Cambridge, MA.

McCullough, D. A., and M. A. DeLorenzo. 1996. Effects of price and management level on optimal replacement and insemination decisions. J. Dairy Sci. 79:242-253.

Miranda, M. J., and P. L. Fackler. 2002. Applied Computational Economics and Finance. MIT Press, Cambridge, MA.

MTT Agrifood Research Finland. 2006. Rehutaulukot ja ruokintasuositukset (Feed tables and feeding recommendations). MTT Agrifood Research Finland, Jokioinen, Finland. http://www.mtt.fi/ mtts/pdf/mtts106.pdf Accessed Feb. 11, 2007.

Perotto, D., R. I. Cue, and A. J. Lee. 1992. Comparison of nonlinear functions for describing the growth curve of three genotypes of dairy cattle. Can. J. Anim. Sci. 72:773-782.

ProAgria. 2006. Mallilaskelmia maataloudesta 2006 (Model calculations about agriculture). ProAgria Maaseutukeskusten Liiton julkaisuja 1030. ProAgria, Helsinki, Finland. In Finnish.

Rajala, P. J., and Y. T. Gröhn. 1998. Effects of dystocia, retained placenta, and metritis on milk yield in dairy cows. J. Dairy Sci. 81:3172-3181.

Rajala-Schultz, P. J., Y. T. Gröhn, and H. G. Allore. 2000. Optimizing replacement decisions for Finnish dairy herds. Acta Vet. Scand. 41:185-198.

Rajala-Schultz, P. J., Y. T. Gröhn, and C. E. McCulloch. 1999a. Effects of milk fever, ketosis, and lameness on milk yield in dairy cows. J. Dairy Sci. 82:288-294.

Rajala-Schultz, P. J., Y. T. Gröhn, C. E. McCulloch, and C. L. Guard. 1999b. Effects of clinical mastitis on milk yield in dairy cows. J. Dairy Sci. 82:1213-1220.

Statistics Finland. 2007. Agricultural Price Indices. The index of purchase prices of the means of agricultural production, Veterinary expenses. http://pxweb2.stat.fi/database/StatFin/hin/ttohi/ ttohi_en.asp Accessed Nov. 8, 2007.

Stott, A. W., and J. O. Kennedy. 1993. The economics of culling dairy cows with clinical mastitis. Vet. Rec. 133:494-499.

Stott, A. W., G. M. Jones, G. J. Gunn, M. Chase-Topping, R. W. Humphry, H. Richardson, and D. N. Logue. 2002. Optimum replacement policies for the control of subclinical mastitis due to S. aureus in dairy cows. J. Agric. Econ. 53:627-644.

Tike. 2007. Monthly Review of Agricultural Statistics 5/2007. Information Centre of the Ministry of Agriculture and Forestry, Helsinki, Finland.

Toivakka, M., J. I. Nousiainen, and E. A. Mäntysaari. 2005. Estimation of economic values of longevity and other functional traits in Finnish dairy cattle. Page 54 in Book of Abstracts of the 56th Annu. Mtg. Eur. Assoc. Anim. Prod., Uppsala, Sweden. Y. van der Honing, ed. Wageningen, the Netherlands. (Abstr.) 